DIW BERLIN

Discussion

Papers
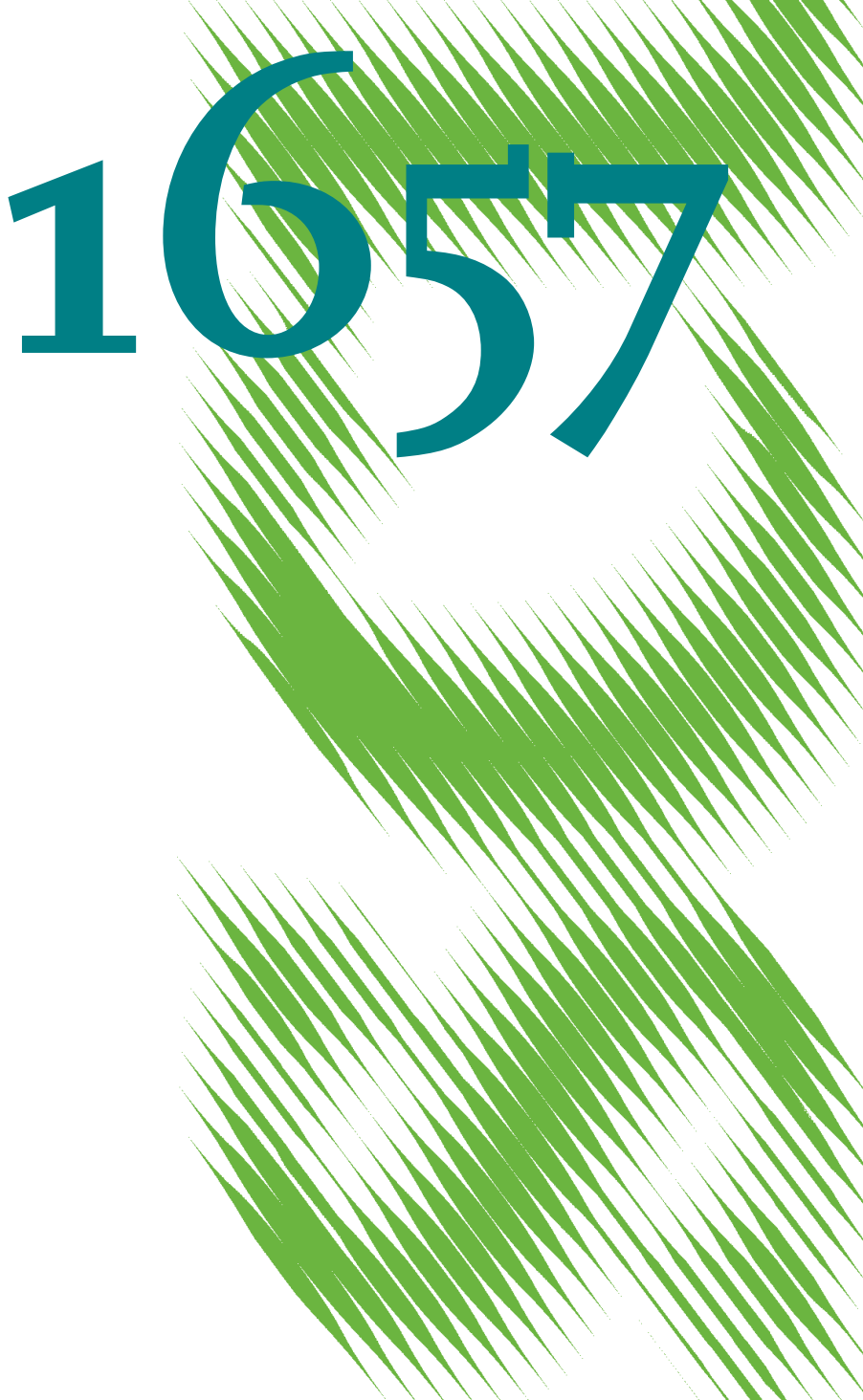

1210

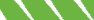

Fathers, Parental Leave and Gender Norms 
Opinions expressed in this paper are those of the author(s) and do not necessarily reflect views of the institute.

IMPRESSUM

(C) DIW Berlin, 2017

DIW Berlin

German Institute for Economic Research

Mohrenstr. 58

10117 Berlin

Tel. +49 (30) $89789-0$

Fax +49 (30) $89789-200$

http://www.diw.de

ISSN electronic edition 1619-4535

Papers can be downloaded free of charge from the DIW Berlin website:

http://www.diw.de/discussionpapers

Discussion Papers of DIW Berlin are indexed in RePEc and SSRN:

http://ideas.repec.org/s/diw/diwwpp.html

http://www.ssrn.com/link/DIW-Berlin-German-Inst-Econ-Res.html 


\title{
Fathers, parental leave and gender norms
}

\author{
Ulrike Unterhofer and Katharina Wrohlich*
}

April 2017

\begin{abstract}
Social norms and attitudes towards gender roles have been shown to have a large effect on economic outcomes of men and women. Many countries have introduced policies that aim at changing gender stereotypes, for example fathers' quota in parental leave schemes. In this paper, we analzye whether the introduction of the fathers' quota in Germany in 2007, that caused a sharp increase in the take-up of parental leave by fathers, has changed the attitudes towards gender roles in the grandparents' generation. To this end, we exploit the quasi-experimental setting of the 2007 reform and compare grandparents whose son had a child born before the 2007 reform to grandparents whose son had a child born after it. Our results suggest that such policy programs not only induce direct behavioral responses by the target group but also have indirect effects on non-treated individuals through social interaction and can thus change attitudes towards gender roles in a society as a whole.
\end{abstract}

JEL-Classification: J16, H31, J18, D13, J22

Key-Words: $\quad$ Parental leave, gender equality, social norms, social interaction, policy evaluation

\footnotetext{
* Corresponding author: kwrohlich@diw.de.

This research has been conducted while Ulrike Unterhofer was a guest researcher at the Public Economics Department of DIW Berlin and Katharina Wrohlich was a research associate at the Public Economics Department and the Gender Studies Research Group of DIW Berlin.
} 


\section{Introduction}

Despite a constant increase in the female labor force participation rate over the last decades, women and men have still not reached an equal position in the labor market. In all OECD countries, there is a considerable gender wage gap, a gender gap in working hours as well as a gender representation gap in leadership positions. Social norms, in particular attitudes towards gender roles, have been shown to have a strong influence on the economic outcomes of men and women, for example by affecting the gender identity of men and women (see, among others, Akerlof and Kranton, 2000, Fortin, 2005 and 2015, Fernandez et al., 2004, Farré and Vella, 2013, Olivetti et al., 2016).

Several countries have introduced various policy measures aiming to combat persisting gender differences in the labor market. Examples for such policies are equal pay legislation ${ }^{1}$ or gender quota for boards of directors of large companies. ${ }^{2}$ These policies intend to directly influence economic outcomes of men and women on the labor market. On the other hand, family policies such as fathers' quota within parental leave programs aim at influencing the behavior of fathers with newborn children and thus indirectly affect labor market outcomes of men and women. ${ }^{3}$ Moreover, these policies are motivated by the idea that they might change social norms and attitudes towards gender roles within society.

\footnotetext{
${ }^{1}$ For example, Iceland has passed a law in early 2017 that will require the biggest companies and government agencies to undergo audits to obtain certification of compliance with equal pay rules. ${ }^{2}$ See Terjesen et al. (2015) for an overview of countries that have introduced binding or non-binding gender quota for boards.

${ }^{3}$ Meier and Rainer (2017) have shown that such policies can also be efficiency enhancing since they enable couples to overcome hold-up problems in the context of parental leave by fathers.
} 
Numerous studies show that gender identity as well as attitudes towards gender roles are strongly determined by one's parents and peers (e.g. Olivetti et al. 2016, Farré and Vella, 2013, Fernandez et al., 2004 or Cunningham, 2001). Furthermore, it has been shown that also institutional environments or policies can influence attitudes (e.g. Sjöberg, 2004, Kotsadam and Finseraas, 2011 or Bauernschuster and Rainer, 2012), for example as policy feedback effects (e.g. Ellingsaeter et al., 2016).

We contribute to both strands of the literature by analyzing whether the introduction of the fathers' quota in parental leave in Germany in 2007, that caused a sharp increase in the take-up of parental leave by fathers, has changed the attitudes towards gender roles in the grandparents' generation. Attitudes towards gender roles within this group are far less studied than attitudes by the younger generation ${ }^{4}$, however are also highly relevant since the grandparents are important mutlipliers for several reasons. First, they might influence attitudes of younger children. Second, to the extent that they are still engaged in the labor market, they might have an influence on attitudes and decisions of their younger coworkers. Last, but not least, they are an important group of voters.

To identify the effect of the fathers' quota in parental leave on the attitudes towards gender roles in the grandparents' generation, we exploit the quasi-experimental setting of the 2007 reform and compare grandparents whose son had a child born before the 2007 reform to grandparents whose son had a child born after it. The empirical analysis is based on the pairfam data set ("Panel Analysis of Intimate Relationships and Family Dynamics"), which is a longitudinal survey that interviews anchor persons and their partners, parents and

\footnotetext{
${ }^{4}$ Kotsdam and Finseraas (2011) have analyzed the effect of the introduction of a fathers' quota in parental leave in Norway on attitudes and behavior within the parents' generation using a similar identification strategy.
} 
children (see Huinink et al., 2011). The advantage of this data set is that it contains - in addition to the standard socio-economic characteristics and gender role attitudes - detailed information on the quality of the relationship between the anchor person and all other members of the family network. For the German context, it is thus uniquely suitable for the empirical analysis of our research question.

Our findings point to a positive impact of the fathers' quota on attitudes concerning gender equality and thus provide evidence for policy feedback effects that have also been shown in other contexts. ${ }^{5}$ Specifically, we find that grandmothers whose sons were more likely to take parental leave as their child was born after the reform, are less likely to agree with the statement "Women should be more concerned about their family than about their career". For grandfathers, we find point estimates of the same direction, however, they are not statistically significant. These results provide evidence that the formation of gender role attitudes is not finished at a certain age. Moreover, attitudes towards gender roles are not only transmitted from parents to children but also from (grown-up) children to their parents.

From a policy perspective, these results provide evidence that programs such as father's quota within parental leave schemes not only induce direct behavioral responses by the target group but also have indirect effects on non-treated individuals through social interaction and can thus meet the goal of changing attitudes towards gender roles in a society as a whole.

\footnotetext{
${ }^{5}$ For example, Ellingsaeter et al. (2016) have shown evidence for policy feedback effects of childcare reforms in Norway.
} 


\section{Parental Leave in Germany}

Traditionally, mothers in Germany have taken very long parental leaves, particularly in West Germany (e.g. Hanel and Riphahn, 2012). This can be attributed both to an institutional setting that discourages secondary earners through the tax system (e.g. Steiner and Wrohlich, 2004) as well as the lack of affordable child care (e.g. Wrohlich, 2008) and to relatively conservative gender role attitudes, in particular in West Germany (Bauernschuster and Rainer, 2012). However, in the last decade, family policy has changed 6 and there has also been a shift towards slightly more egalitarian views on gender roles (Blohm and Walter, 2016).

In Germany, mothers are entitled to 14 weeks of paid maternity leave around childbirth. This maternity leave benefit is only paid to mothers and cannot be transferred to fathers. Before 2007, there has been a means-tested child-rearing benefit (Erziehungsgeld) after the 14 week maternity leave period. This benefit amounted to 300 Euro per month and could be drawn for a maximum of two years either by the father or the mother. Income thresholds, however, have been relatively low, such that only roughly 50 percent of families received this benefit. ${ }^{7}$ In practice this resulted in a very low share of fathers taking leave (Geisler and Kreyenfeld, 2012), and relatively long employment interruptions of mothers (e.g. Hanel and Riphahn, 2012).

The reform that was introduced in 2007 replaced the means-tested Erziehungsgeld with an earnings-replacement benefit called Elterngeld. This benefit replaces 65 percent of net

\footnotetext{
${ }^{6}$ In the last decade, Germany has introduced not only a major parental leave reform but also various reforms concerning childcare policy, see e.g. Müller and Wrohlich (2016).

${ }^{7}$ See Wrohlich et al. (2012).
} 
earnings and can be drawn either by the father or the mother for a maximum of 12 months. If both parents share parental leave, they are entitled to two additional months, i.e. if one parent takes at least two months of parental leave, the total duration for the couple is extended to 14 months. In other words, at least two months of the leave are earmarked for the father; if he does not take these months, the maximum length of paid leave is cut from 14 to 12 months. ${ }^{8}$

Figure 1: Share of children born between 2004 and 2012 whose fathers took parental leave

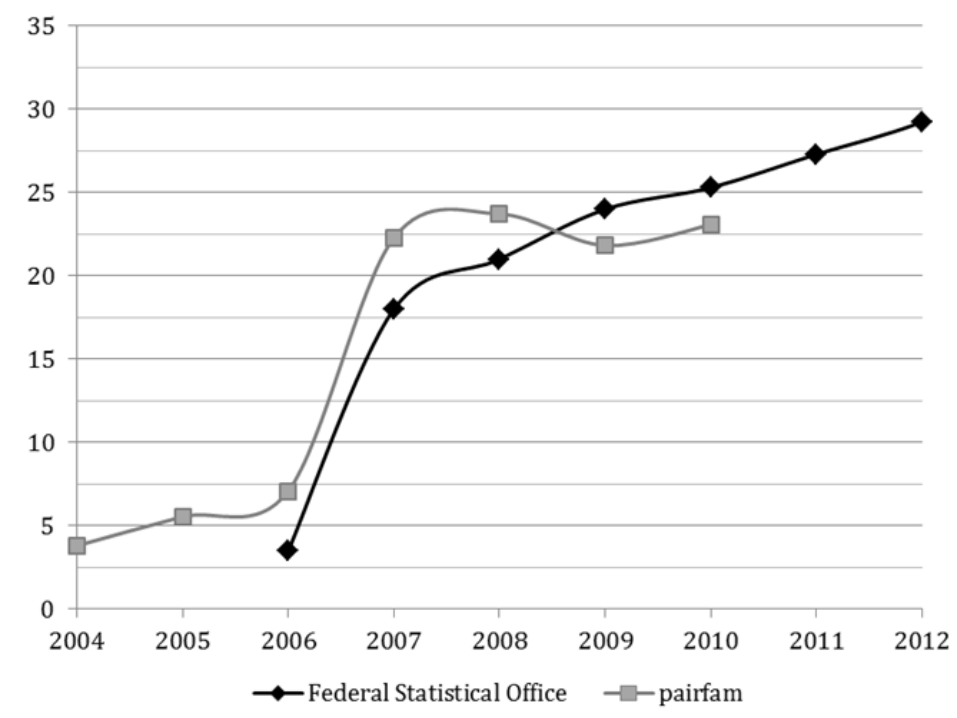

Source: Own depiction based on data from the Federal Statistical Office (Bundeselterngeldstatistik) and pairfam, wave 5 (2012/13).

The reform lead to a sharp increase in the take-up of parental leave by fathers (see, for example, Geisler and Kreyenfeld, 2012). Figure 1 shows the development of the share of

\footnotetext{
${ }^{8}$ Several other countries have similar fathers' quota as part of their parental leave schemes. For example, Norway and Sweden introduced these policies already in the 1990s (see Dahl et al., 2014, Cools et al., 2015, or Ekberg et al., 2013). Other countries such as Italy, Germany, Austria and Portugal have followed. For an overview on these policies in OECD countries, see Huerta et al. (2013).
} 
fathers taking parental leave based on administrative data as well as from the pairfam data that we will use for our empirical analysis. The administrative data, which are based on all applications to the parental leave benefit in Germany, show that the share of fathers taking parental leave has increased from about three percent in 2006 to 30 percent in 2012. In particular, there has been a sharp increase in the share of fathers taking parental leave immediately after the reform, i.e. from 2006 to 2007 . However, even in the years after the reform, a continuing positive trend can be observed. The same pattern is also visible in the pairfam data.

Enhancing gender equality was one important policy goal of the introduction of the new parental leave scheme in 2007. Its design as an earnings replacement benefit was meant to allow both parents to preserve their personal economic independence. The fathers' quota of two out of 14 months was explicitly introduced to increase the share of fathers taking parental leave. Several empirical evaluation studies of this reform show that these goals were at least partly met: The share of mothers going back to work in the second year after giving child birth has increased. The duration of parental leave has decreased in particular for lower educated mothers (see, among others, Bergemann and Riphahn, 2011, Kluve and Tamm, 2013 or Geyer et al., 2015). As has been shown above, the share of fathers taking parental leave increased from less than three to 30 percent in 2012. There is evidence that this increase in fathers' leave taking has already moderately affected the labor division between mothers and fathers (Schober, 2014). 


\section{Research Design and Identification}

The objective of this paper is to analyze whether the introduction of the fathers' quota, that has sharply increased the share of fathers who take parental leave, has affected the attitudes towards gender roles in the grandparent generation via social interaction between fathers and their parents. In particular, we are interested whether grandparents who observe their son taking parental leave change their attitudes towards gender roles. We will measure the attitudes towards gender roles by the agreement/disagreement to the statement "Women should be more concerned about their family than about their career". More details on this variable are provided in section 4 .

As Manski (1993) pointed out, there are several threats to the identification of endogenous, i.e. 'true', social interaction effects. In the context of social interaction within the family, two major challenges arise. First, it is difficult to distinguish endogenous social interaction effects from correlated effects. Unobservable (but relevant) variables could cause omitted variable bias, if they are correlated among individuals belonging to the same family. For example, neighborhood characteristics could be distributed non-uniformly across families and thus bias the results. Second, there exists a simultaneity in the behavior of interacting individuals. The choices of the individuals in one group have an influence on the choices of other group members, which hampers the identification of true social interaction effects (reflection problem, see Manski, 1993). ${ }^{9}$

In the literature on social interaction effects, different approaches for the identification of social interaction effects have been employed. Several non-experimental studies try to solve

\footnotetext{
${ }^{9}$ In other contexts, endogenous group membership is another problem for identification. However, in the family context, this is not relevant as the member status is predetermined by birth.
} 
the problems arising from potential simultaneity, correlated unobservables and endogenous group membership by narrowing peer groups and controlling for covariates. ${ }^{10}$ Others have exploited random assignment to peer groups. ${ }^{11}$ More recently, several studies have used quasi-experimental settings to solve the simultaneity problems in the context of social interaction within naturally occurring peer groups. For example, Angelucci et al. (2010) and Lalive and Cattaneo (2009) study indirect effects of a social assistance program in Mexico, Brown and Laschever (2012) examine the peer effects of a pension reform. Dahl et al. (2014) exploit the introduction of a fathers' quota in parental leave in Norway in order to analyze peer effects in parental leave taking among brothers, neighbors and colleagues at work. Welteke and Wrohlich (2016) use a similar identification strategy and exploit the introduction of the German 2007 parental leave reform in order to analyze peer effects in parental leave taking of mothers who are colleagues at work.

We follow the same identification approach and use the introduction of the fathers' quota in parental leave in 2007 in Germany as a natural experiment in order to avoid simultaneity issues. ${ }^{12}$ As has been shown in Figure 1, the reform resulted in a large increase in the share of fathers who take parental leave. This discontinuity is exploited for identification of the social interaction effect.

In our empirical analysis, we apply the partial population approach developed by Moffitt (2001) ${ }^{13}$, which exploits the fact that a policy intervention exogenously ${ }^{14}$ assigns a

\footnotetext{
${ }^{10}$ See, for example, Betrand et al., 2000.

${ }^{11}$ Sacerdote, 2001 or Kling, Ludwig and Katz, 2005.

12 However, our analysis differs from the aforementioned studies in the way that we analyze the effect of the behavior of one individual (namely parental leave-taking of a father) on the attitudes of another individual (namely the attitudes towards gender roles of the grandmother or the grandfather). Most other studies in the literature on peer effects analyze the effects of the behavior of one group member on the behavior of other group members.

${ }^{13}$ Dahl et al. (2014) were the first to use this approach in the context of peer effects.
} 
treatment only to a subset of the population. For illustration, consider the following system of simultaneous equations:
(1) $y_{F g}=\alpha_{F}+\beta_{F} y_{P U g}+\gamma_{F} x_{F g}+\delta_{F} x_{P U g}+\theta_{F} w_{g}+\lambda p_{g}+\varepsilon_{F g}$
(2) $y_{P U g}=\alpha_{P U}+\beta_{P U} y_{F g}+\gamma_{P U} x_{P U g}+\delta_{P U} x_{F g}+\theta_{P U} w_{g}+\varepsilon_{P U g}$

Suppose that there are $g=1, \ldots, G$ groups (i.e. families) and two individuals $i=F, P U$, the father $(F)$ and his parental unit $(P U)$. In our context, $y_{P}$ denotes the probability of father $F$ to take parental leave while $y_{P U}$ contains the grandparent's gender attitudes. Let $x_{i g}$ denote observable characteristics of individual $i$ in group $g, w_{g}$ are characteristics varying at group level and epsilon be the unobservable error term. Based on the definition of Manski (1993), $\delta$ presents the presence of exogenous effects, while $\beta$ measures endogenous social interactions. The policy variable $p_{g}$ in equation (1) that can be interpreted as the price of taking parental leave, serves as exclusion restriction.

The reduced form of this model can be interpreted as the intention to treat effect of having a son who had a child after the reform on the grandparents' attitudes towards gender roles:

$$
\text { (3) } y_{P U g}=\alpha_{P U}+\gamma_{P U} x_{P U g}+\delta_{P U} x_{F g}+\theta_{P U} w_{g}+\lambda p_{g}+\epsilon_{P U g}
$$

One of the identifying assumptions is that this policy variable is independent of all unobservables in the model. In our context, this variable relates to the cost of paternity leave that changed with the German parental leave reform in 2007 (see section 2). This

\footnotetext{
${ }^{14}$ See Kluve and Tamm (2013) for a detailed discussion in how far and for what groups the parental leave reform of 2007 in Germany can be interpreted as an exogenous event.
} 
reform encouraged fathers to stay at home for at least two months, creating a discontinuity that allows to compare parents of fathers who had children born shortly before 2007 to parents of fathers who had children shortly after this cut-off. The reform changed the cost of taking parental leave for fathers, however it did not affect the generation of grandparents. Therefore, it is possible to isolate the social interaction effect on attitudes, as the grandparents' attitudes are only affected by the parental leave reform through the behavior, i.e. leave-taking, of their sons. ${ }^{15}$ We use the implementation date of the reform to define the treatment and control groups.

Figure 2 illustrates the identification strategy based on two exemplary families. Fathers who got a child in the observation period determine the treatment status of their parents (grandmother or grandfather of the child). Parents differ only in whether their son had a child before or after the cut-off. They are comparable since they are asked about their attitudes towards gender roles at the same point in time (in 2012/13) and are not directly affected by the reform.

\footnotetext{
${ }^{15}$ Hypothetically, the reform could have affected grandparents in a direct way. For example, the time that grandparents allocate to the care of their grandchildren could have been reduced in the first 14 months after childbirth if the parents themselves delay their return to the labor market as a response to the reform. On the other hand, the increase of the employment rate of mothers with children in the second year after birth could encourage grandparents to play a more active role in childcare in the medium and long run. Nevertheless, a change in the involvement of grandparents would undermine our identification strategy only if the changing patterns of time use would somehow affect the grandparents' attitudes related to gender equality.
} 
Figure 2: Identification of social interaction effects

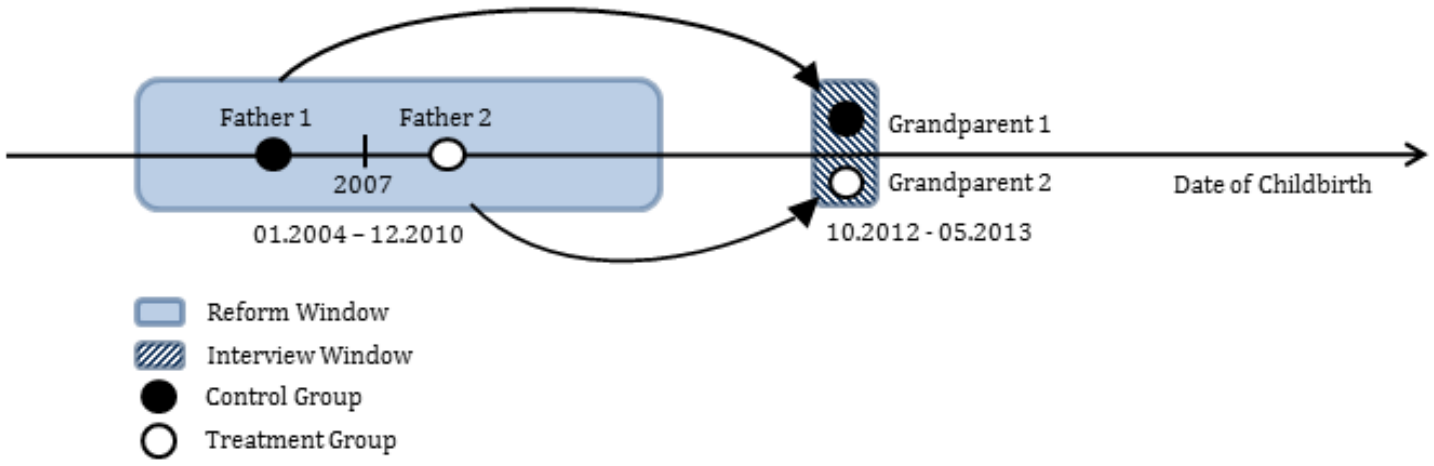

Ideally, one would choose a very short time window around the cut-off date. Kluve and Tamm (2013) as well as Geyer et al. (2015) have argued that mothers who gave birth to a child in the first three months of 2007 could not have known that the reform would be implemented by January $1^{\text {st }}$ of that year at the time of the conception. Thus, when comparing parents who had a child in the last three months of 2006 to those who had a child in the first three months of 2007, there should be no differences in observed or unobserved characteristics. If the time window around the cut-off date is larger, however, selection into the treatment group cannot be ruled out. The law on the new parental leave scheme has been passed in September 2006, so parents who had children born after July 2007 knew that they would be eligible for the new parental leave scheme.

Unfortunately, the data set that we use (see next section) is relatively small and therefore we have to define treatment and control groups using a larger time window around the reform cut-off date. We define the control group as grandparents who had a grandchild that was born between January 2004 and December 2006 and the treatment group as grandparents who had a grandchild born between January 2007 and December 2010. Since the new parental leave scheme is more attractive for couples with more gender egalitarian 
sharing of market and care work, there could be selection into the treatment group by those couples. If fathers who have more gender egalitarian attitudes also have parents with more egalitarian views, the assumption that the policy variable $p_{g}$ in equation (3) is uncorrelated with the error terms is violated and the estimates are biased.

One advantage of the data set that we use, however, is that we have very detailed information on characteristics that are unobserved in other data sets, such as attitudes towards gender roles. In the next section we will show that although we define treatment and control groups according to this relatively large time window around the cut-off date, fathers and grandparents in both groups do not differ with respect to most observed characteristics. More importantly, fathers in treatment and control groups do not differ in their attitudes towards gender roles (see Table 2 in section 4). We thus argue that the identifying assumptions underlying equation (3) still hold in our context.

Another potential threat to identification is the fact that over the whole observation period (2004 to 2010), Germany has experienced a large increase in the availability of public or publicly subsidized child care, in particular for children under the age of three. While in 2002, the average availability of child care for children under three was about 2 percent in West Germany, it increased up to 22 percent by the year 2012.16 This increase was unevenly spread over Germany since the decision about the supply of or subsidies to childcare facilities is made on the county level. If the increase in childcare availability influenced attitudes towards gender roles, ${ }^{17}$ the treatment variable might in fact not pick up the

\footnotetext{
${ }^{16}$ See Müller and Wrohlich (2016). In East Germany, availability of childcare has traditionally been higher, however also increased strongly between 2002 (35 percent) and 2012 (52 percent).

${ }^{17}$ Ellingsaeter et al. (2016) show for the case of Norway, that an expansion of public child care changed attitudes towards private and out-of home child care among Norwegian mothers.
} 
introduction of the fathers' quota in the parental leave scheme but rather the increase in childcare availability. We therefore control for the increase in the child care quota between 2002 and 2012 on the regional level.

By construction of the quasi-experimental set-up, the average age of the youngest child is lower in the treatment than in the control group. This might as well affect the attitudes of grandparents. One could imagine that grandparents in the treatment group might react differently to the questions related to gender roles in child care as they will perceive the statements in the survey out of a different context (with a baby or toddler in mind) than grandparents in the control group (potentially having in mind an older child). Consequently, one could argue that it is not the reform causing a change in attitudes but that the results are rather driven by the age of the grandchild. We take this potential effect into account by including age of the youngest child as a control variable in the regression.

\section{Data}

The empirical analysis is based on the German Family Panel pairfam ("Panel Analysis of Intitimate Relationships"). This longitudinal study focusses on the partnership and family formation process and development as well as intergenerational relationships. It has been launched in 2008 and collects data from a nationwide random sample of more than 12,000 persons of the three birth cohorts 1971-73, 1981-83 and 1991-93. In addition to the interviews of these anchor persons, the data set also provides detailed information on the anchor person's partners, parents and children. ${ }^{18}$ This multi-actor design is the main advantage of the pairfam data in our context. In addition to the anchor persons, from which

${ }^{18}$ A detailed description of the study can be found in Huinink et al. (2011). 
we draw the sample of fathers in our analysis, interviews are conducted with the anchor's parents. Moreover, the data contain very detailed information on the relationship between family members such as emotional closeness or the frequency of contact.

In our analysis, we mainly use data from wave $5(2012 / 13)$ where the anchor persons as well as their parents are asked about gender related values such as the attitudes towards the division of labor in the partnership and to mothers' and fathers' professional or occupational commitment. We restrict the sample to male anchor persons who had their youngest child born between January 2004 and December 2010. This leaves us with 740 fathers. In the next step, the (grand)parents are matched to the sample of anchor persons (fathers). Each anchor is linked to a maximum of three parents, i.e. either the biological father and mother or step-parents. For parents who dropped out of the survey before wave 5, data from wave 3 (2010/11) containing the same question module was considered. Unfortunately matching parent units can only be identified for 36 percent of the anchor persons ${ }^{19}$ so that we end up with a final sample of 265 anchor-(grand)parent matches (156 father-grandmother and 109 father-grandfather matches).

Table 1 shows descriptive statistics of all relevant observable characteristics of fathers and grandparents for the treatment and control group. T-tests show that there is no statistically significant difference in mean values of these variables except for "age of the youngest child" - which is true per definition (see Figure 1). Grandfathers and -mothers are in their 60s and have comparable years of education. More than one third of grandfathers is still working while the share of working grandmothers is slightly lower. On average, 72 percent

\footnotetext{
${ }^{19}$ The pairfam sampling report (Suckow, Schneekloth and Wich, 2010) documents the matching process of anchors and their parents and the reasons why matches are not successful in many cases.
} 
of grandmothers have been working when their son was under the age of six. Emotional closeness and frequency of contact between family members is evenly distributed across groups. ${ }^{20}$ On average, grandmothers report to be more attached to their sons than grandfathers.

Table 1: Descriptive statistics, sample of grandparents

\begin{tabular}{|c|c|c|c|c|c|c|}
\hline & \multicolumn{3}{|c|}{ Grandmothers } & \multicolumn{3}{|c|}{ Grandfathers } \\
\hline & Control & Treated & t-Test & Control & Treated & $\mathrm{t}$-Test \\
\hline \multicolumn{7}{|l|}{ Grandparent unit } \\
\hline Age & $\begin{array}{l}65.14 \\
(7.389)\end{array}$ & $\begin{array}{l}63.27 \\
(6.791)\end{array}$ & $\begin{array}{l}1.865 \\
(1.247)\end{array}$ & $\begin{array}{l}67.97 \\
(7.263)\end{array}$ & $\begin{array}{l}65.50 \\
(7.304)\end{array}$ & $\begin{array}{l}2.466 \\
(1.581)\end{array}$ \\
\hline Years of education & $\begin{array}{l}12.61 \\
(2.855)\end{array}$ & $\begin{array}{l}12.43 \\
(2.437)\end{array}$ & $\begin{array}{l}0.186 \\
(0.458)\end{array}$ & $\begin{array}{l}12.84 \\
(3.030)\end{array}$ & $\begin{array}{l}12.94 \\
(2.461)\end{array}$ & $\begin{array}{l}-0.101 \\
(0.568)\end{array}$ \\
\hline Currently employed & $\begin{array}{l}0.302 \\
(0.465)\end{array}$ & $\begin{array}{l}0.336 \\
(0.475)\end{array}$ & $\begin{array}{l}-0.034 \\
(0.085)\end{array}$ & $\begin{array}{l}0.345 \\
(0.484)\end{array}$ & $\begin{array}{l}0.425 \\
(0.497)\end{array}$ & $\begin{array}{l}-0.080 \\
(0.107)\end{array}$ \\
\hline Employed when kids $<6$ & $\begin{array}{l}0.721 \\
(0.454)\end{array}$ & $\begin{array}{l}0.717 \\
(0.453)\end{array}$ & $\begin{array}{l}0.004 \\
(0.081)\end{array}$ & & & \\
\hline Migration background & $\begin{array}{l}0.0233 \\
(0.152)\end{array}$ & $\begin{array}{l}0.124 \\
(0.331)\end{array}$ & $\begin{array}{l}-0.101 \\
(0.0525)\end{array}$ & $\begin{array}{l}0.035 \\
(0.186)\end{array}$ & $\begin{array}{l}0.100 \\
(0.302)\end{array}$ & $\begin{array}{l}-0.066 \\
(0.060)\end{array}$ \\
\hline Frequent contact & $\begin{array}{l}0.744 \\
(0.441)\end{array}$ & $\begin{array}{l}0.832 \\
(0.376)\end{array}$ & $\begin{array}{l}-0.0877 \\
(0.071)\end{array}$ & $\begin{array}{l}0.690 \\
(0.471)\end{array}$ & $\begin{array}{l}0.750 \\
(0.436)\end{array}$ & $\begin{array}{l}-0.060 \\
(0.097)\end{array}$ \\
\hline Emotional closeness & $\begin{array}{l}0.395 \\
(0.495)\end{array}$ & $\begin{array}{l}0.478 \\
(0.502)\end{array}$ & $\begin{array}{l}-0.083 \\
(0.090)\end{array}$ & $\begin{array}{l}0.345 \\
(0.484)\end{array}$ & $\begin{array}{l}0.375 \\
(0.487)\end{array}$ & $\begin{array}{l}-0.030 \\
(0.105)\end{array}$ \\
\hline $\begin{array}{l}\text { Age of grandchild } \\
\text { (linear) }\end{array}$ & $\begin{array}{l}2.256 \\
(0.819)\end{array}$ & $\begin{array}{l}5.566 \\
(1.117)\end{array}$ & $\begin{array}{l}-3.311^{\star \star \star} \\
(0.187)\end{array}$ & $\begin{array}{l}2.241 \\
(0.786)\end{array}$ & $\begin{array}{l}5.563 \\
(1.112)\end{array}$ & $\begin{array}{l}-3.321^{\star \star \star} \\
(0.225)\end{array}$ \\
\hline Wave 3 & $\begin{array}{l}0.256 \\
(0.441)\end{array}$ & $\begin{array}{l}0.0973 \\
(0.298)\end{array}$ & $\begin{array}{l}0.158^{*} \\
(0.0615)\end{array}$ & $\begin{array}{l}0.207 \\
(0.412)\end{array}$ & $\begin{array}{l}0.063 \\
(0.244)\end{array}$ & $\begin{array}{l}0.144^{*} \\
(0.064)\end{array}$ \\
\hline $\begin{array}{l}\text { Delta child care quota } \\
2002-2012\end{array}$ & $\begin{array}{l}0.167 \\
(0.0691)\end{array}$ & $\begin{array}{l}0.168 \\
(0.0699)\end{array}$ & $\begin{array}{l}-0.0010 \\
(0.0125)\end{array}$ & $\begin{array}{l}0.152 \\
(0.073)\end{array}$ & $\begin{array}{l}0.160 \\
(0.075)\end{array}$ & $\begin{array}{l}-0.009 \\
(0.016)\end{array}$ \\
\hline Region: East Germany & $\begin{array}{l}0.442 \\
(0.502)\end{array}$ & $\begin{array}{l}0.416 \\
(0.495)\end{array}$ & $\begin{array}{l}0.026 \\
(0.089)\end{array}$ & $\begin{array}{l}0.483 \\
(0.509)\end{array}$ & $\begin{array}{l}0.475 \\
(0.503)\end{array}$ & $\begin{array}{l}0.008 \\
(0.109)\end{array}$ \\
\hline $\begin{array}{l}\text { Region: Berlin, } \\
\text { Hamburg, Bremen }\end{array}$ & $\begin{array}{l}0.047 \\
(0.213)\end{array}$ & $\begin{array}{l}0.0177 \\
(0.132)\end{array}$ & $\begin{array}{l}0.029 \\
(0.028)\end{array}$ & $\begin{array}{l}0.0345 \\
(0.186)\end{array}$ & $\begin{array}{l}0.025 \\
(0.157)\end{array}$ & $\begin{array}{l}0.009 \\
(0.036)\end{array}$ \\
\hline $\begin{array}{l}\text { Region: Hesse, } \\
\text { Rhineland-Palatinate, } \\
\text { Saarland }\end{array}$ & $\begin{array}{l}0.070 \\
(0.258)\end{array}$ & $\begin{array}{l}0.106 \\
(0.309)\end{array}$ & $\begin{array}{l}-0.036 \\
(0.053)\end{array}$ & $\begin{array}{l}0.069 \\
(0.258)\end{array}$ & $\begin{array}{l}0.113 \\
(0.318)\end{array}$ & $\begin{array}{l}-0.044 \\
(0.066)\end{array}$ \\
\hline Region: Bavaria & $\begin{array}{l}0.046 \\
(0.213)\end{array}$ & $\begin{array}{l}0.142 \\
(0.350)\end{array}$ & $\begin{array}{l}-0.095 \\
(0.057)\end{array}$ & $\begin{array}{l}0.069 \\
(0.258)\end{array}$ & $\begin{array}{l}0.100 \\
(0.302)\end{array}$ & $\begin{array}{l}-0.031 \\
(0.063)\end{array}$ \\
\hline $\begin{array}{l}\text { Region: Baden- } \\
\text { Wuerttemberg }\end{array}$ & $\begin{array}{l}0.070 \\
(0.258)\end{array}$ & $\begin{array}{l}0.062 \\
(0.242)\end{array}$ & $\begin{array}{l}0.008 \\
(0.044)\end{array}$ & $\begin{array}{l}0.069 \\
(0.258)\end{array}$ & $\begin{array}{l}0.038 \\
(0.191)\end{array}$ & $\begin{array}{l}0.031 \\
(0.046)\end{array}$ \\
\hline $\begin{array}{l}\text { Region: Lower Saxony } \\
\text { and Schleswig-Holstein }\end{array}$ & $\begin{array}{l}0.140 \\
(0.351)\end{array}$ & $\begin{array}{l}0.115 \\
(0.320)\end{array}$ & $\begin{array}{l}0.025 \\
(0.059)\end{array}$ & $\begin{array}{l}0.069 \\
(0.258)\end{array}$ & $\begin{array}{l}0.100 \\
(0.302)\end{array}$ & $\begin{array}{l}-0.031 \\
(0.063)\end{array}$ \\
\hline Number of observations & 43 & 113 & 156 & 29 & 80 & 109 \\
\hline
\end{tabular}

Note: Standard errors in parentheses. All reported values are unweighted.

${ }^{*} p<0.05,{ }^{* *} p<0.01,{ }^{* * *} p<0.001$

Source: pairfam, waves 3 (2010/11) and 5 (2012/13).

\footnotetext{
${ }^{20}$ The variable "frequent contact" is a dummy taking on the value $1 \mathrm{f}$ the father and his mother or father are in contact at least once a week. "Emotional closeness" is also a dummy that is equal to 1 if grandparents describe their relationship to their son as being "very close".
} 
Also fathers' characteristics are similar across treatment and control groups (see Table 2).

Due to the design of the quasi-experiment, fathers in the treatment group on average are younger at the time of the grandparents' interview. The difference in father's age is thus statistically significant. In our sample, no father in the control group took parental leave. In the treatment group, the share of fathers taking parental leave is 24 percent. In the whole sample of the pairfam data set, the share of fathers taking parental leave nicely fits the aggregate statistics provided by the German Federal Statistical Office (see Figure 1 in section 2).

Table 2: Descriptive statistics, sample of fathers

\begin{tabular}{|c|c|c|c|c|c|c|}
\hline & \multicolumn{3}{|c|}{ Grandmothers } & \multicolumn{3}{|c|}{ Grandfathers } \\
\hline & Control & Treated & $\mathrm{t}$-Test & Control & Treated & $\mathrm{t}$-Test \\
\hline \multicolumn{7}{|l|}{ Father } \\
\hline $\begin{array}{l}\text { Father takes parental } \\
\text { leave }\end{array}$ & $\begin{array}{l}0 \\
(0)\end{array}$ & $\begin{array}{l}0.250 \\
(0.435)\end{array}$ & $\begin{array}{l}-0.239^{\star \star \star} \\
(0.066)\end{array}$ & $\begin{array}{l}0 \\
(0)\end{array}$ & $\begin{array}{l}0.253 \\
(0.438)\end{array}$ & $\begin{array}{l}-0.237^{\star \star} \\
(0.080)\end{array}$ \\
\hline Age & $\begin{array}{l}39.86 \\
(2.706)\end{array}$ & $\begin{array}{l}37.21 \\
(5.026)\end{array}$ & $\begin{array}{l}2.578^{\star \star} \\
(0.829)\end{array}$ & $\begin{array}{l}39.46 \\
(3.203)\end{array}$ & $\begin{array}{l}37.28 \\
(4.758)\end{array}$ & $\begin{array}{l}1.891 \\
(0.978)\end{array}$ \\
\hline Number of kids & $\begin{array}{l}1.972 \\
(0.816)\end{array}$ & $\begin{array}{l}1.923 \\
(0.888)\end{array}$ & $\begin{array}{l}0.0796 \\
(0.154)\end{array}$ & $\begin{array}{l}2.000 \\
(0.834)\end{array}$ & $\begin{array}{l}2.068 \\
(0.930)\end{array}$ & $\begin{array}{l}0.0690 \\
(0.192)\end{array}$ \\
\hline Years of education & $\begin{array}{l}14.97 \\
(3.342)\end{array}$ & $\begin{array}{l}14.91 \\
(3.022)\end{array}$ & $\begin{array}{l}-0.128 \\
(0.557)\end{array}$ & $\begin{array}{l}14.63 \\
(3.187)\end{array}$ & $\begin{array}{l}14.91 \\
(3.167)\end{array}$ & $\begin{array}{l}-0.568 \\
(0.679)\end{array}$ \\
\hline Employed & $\begin{array}{l}0.953 \\
(0.213)\end{array}$ & $\begin{array}{l}0.965 \\
(0.186)\end{array}$ & $\begin{array}{l}-0.011 \\
(0.035)\end{array}$ & $\begin{array}{l}0.965 \\
(0.185)\end{array}$ & $\begin{array}{l}0.987 \\
(0.111)\end{array}$ & $\begin{array}{l}-0.022 \\
(0.085)\end{array}$ \\
\hline Married & $\begin{array}{l}0.861 \\
(0.351)\end{array}$ & $\begin{array}{l}0.788 \\
(0.410)\end{array}$ & $\begin{array}{l}0.044 \\
(0.074)\end{array}$ & $\begin{array}{l}0.875 \\
(0.338)\end{array}$ & $\begin{array}{l}0.800 \\
(0.403)\end{array}$ & $\begin{array}{l}0.015 \\
(0.085)\end{array}$ \\
\hline Net income (personal) & $\begin{array}{l}2460.8 \\
(898.3)\end{array}$ & $\begin{array}{l}2868.0 \\
(3853.2)\end{array}$ & $\begin{array}{l}-431.3 \\
(619.5)\end{array}$ & $\begin{array}{l}2397.5 \\
(837.3)\end{array}$ & $\begin{array}{l}2386.2 \\
(1154.7)\end{array}$ & $\begin{array}{l}-34.62 \\
(245.9)\end{array}$ \\
\hline Net income (household) & $\begin{array}{l}5127.0 \\
(8634.9)\end{array}$ & $\begin{array}{l}4125.5 \\
(3984.4)\end{array}$ & $\begin{array}{l}629.7 \\
(972.4)\end{array}$ & $\begin{array}{l}3693.5 \\
(1193.2)\end{array}$ & $\begin{array}{l}3646.5 \\
(1508.6)\end{array}$ & $\begin{array}{l}-258.6 \\
(321.6)\end{array}$ \\
\hline $\begin{array}{l}\text { Response to statement } \\
\text { "Women should be } \\
\text { more concerned } \\
\text { about their family } \\
\text { than about their } \\
\text { career" }\end{array}$ & $\begin{array}{l}2.278 \\
(0.914)\end{array}$ & $\begin{array}{l}2.587 \\
(0.972)\end{array}$ & $\begin{array}{l}-0.294 \\
(0.170)\end{array}$ & $\begin{array}{l}2.292 \\
(0.908)\end{array}$ & $\begin{array}{l}2.573 \\
(0.961)\end{array}$ & $\begin{array}{l}-0.221 \\
(0.201)\end{array}$ \\
\hline Observations & 43 & 113 & 156 & 29 & 80 & 109 \\
\hline
\end{tabular}

Note: Standard errors in parentheses. All reported values are unweighted.

${ }^{*} p<0.05,{ }^{* *} p<0.01,{ }^{* * *} p<0.001$

Source: pairfam, waves 3 (2010/11) and 5 (2012/13).

In order to check whether there is self-selection into the treatment group based on attitudes towards gender roles, we compare the answers to the statement "Women should be more concerned about their family than their career" of the fathers in the treatment and control 
group. Although the approval to this statement is slightly higher in the treatment group (i.e. fathers in the treatment group have slightly less gender egalitarian attitudes), the difference is not statistically significant.

The answers to the statement "Women should be more concerned about their family than about their career" by the grandparents represent the dependent variable in our analysis. In the pairfam survey respondents are asked to rate the degree to which they approve or disapprove of this on a 5-point Likert scale ranging from "disagree completely" (1) to "agree completely" (5). Figure 3 presents the distribution of the Likert-type question for grandmothers and grandfathers of the fathers affected by the reform ("treated") and those not affected ("control"). The figure suggests that both grandmothers (panel a) and grandfathers (panel b) are more likely to state that they "disagree" or "disagree completely" (values 2 and 1, respectively) to the statement "Women should me more concerned about the family than about their career" if they are in the treatment group. The shift to an overall rejection of the statement is visible for both parental units, but seems to be more pronounced for women.

Figure 3: Histogram of answers to the statement: "Women should be more concerned about their family than about their career."

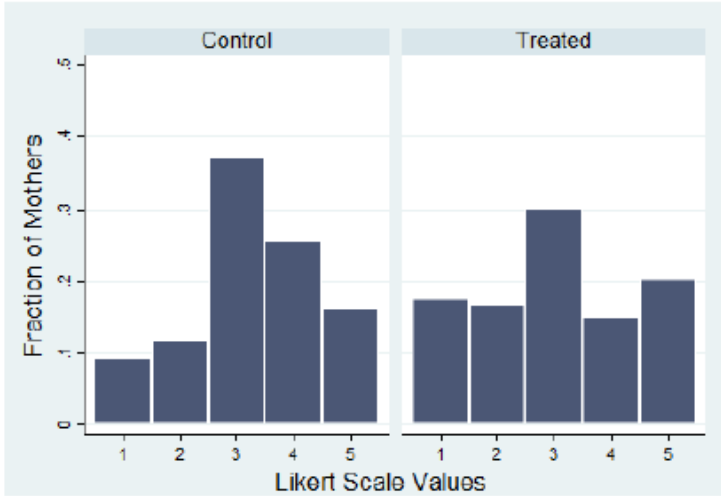

(a) Grandmothers

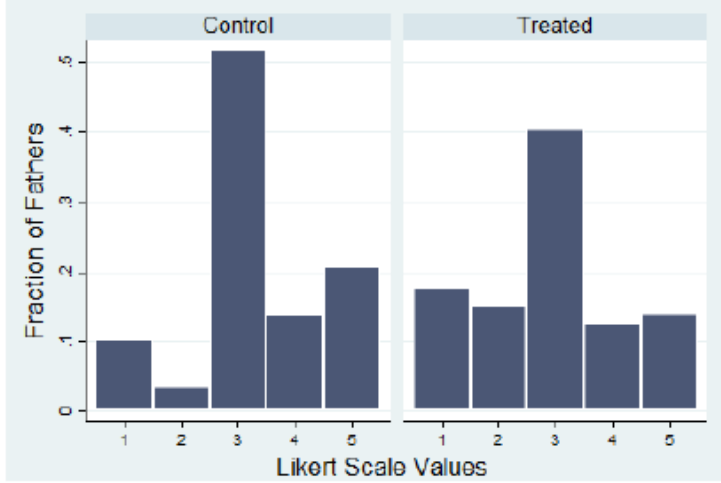

(b) Grandfathers

Source: Calculations based on pairfam, waves 3 (2010/11) and 5 (2012/13). 
The descriptive visual comparison of the Likert-type question across treated and nontreated individuals gives a first insight on potential shifts in gender-role attitudes. As far as the attitudes towards the labor market involvement of mothers are concerned, the distribution of the variable suggests an influence of the parental leave reform on the attitudes of grandparents. Both, grandmothers and grandfathers in the treatment group express a higher degree of disapproval of the statement than those in the control group.. The regression analyses in the next section will give further insights on the magnitude and the statistical significance of social interaction effects induced by an increasing usage of parental leave by fathers.

\section{Estimation Results}

In this section, we present the results of the estimation of equation (3). In our main specification we define the dependent variable as a binary variable that takes on the value 1 if an individual says that he or she "disagrees" or "fully disagrees" with the statement "Women should be more concerned about their family than about their career", and the value 0 if the individual states that he or she "agrees", "fully agrees" or is indifferent to that statement. In an alternative specification, we run ordered probit regressions that use the full information of the distribution of the answers to the statement on the 5-point Likert scale. In both specifications, we find very similar results.

Table 2 summarizes results from an estimation of equation (3) for grandfathers and grandmothers separately. The regression is based on a linear probability model. The variable Post07 captures the treatment effect. For both, grandmothers and grandfathers the plain within-group difference estimator points to an increase in the probability of 
disapproval for the treatment group, i.e. more gender egalitarian views. Including the first set of covariates as well as regional dummies and a control variable for grandparents who have been interviewed in wave 3 (i.e. have been interviewed 2 years earlier than the rest of the sample), increases the absolute size of the point estimate (column II) for both groups. Including the age of the child (column III) and the change in the child care quota on the county level (IV) further increases the point estimate. In this specification, the probability of a grandmother to disagree to the statement "Women should be more concerned about their family than their career" is 28 percentage points higher for those with a son who had a child born after 2007 as compared to those with a son who had a child born before this date. For grandfathers, the point estimator is of similar magnitude (22 percentage points), however is not statistically significant, which is probably due to the even smaller sample size (108 grandfathers versus 156 grandmothers). ${ }^{21}$

Apart from this policy variable, we find hardly any significant predictors of the probability to disagree to the statement "Women should be more concerned about their family than about their career". In the sample of grandmothers, we find that the older the individuals, the less likely they are to disagree to this statement. If grandmothers have been working when their own children were under the age of six, they are more likely to disagree to this statement, i.e. have more gender egalitarian views, however, the coefficient is not statistically significant. Grandmothers who report high levels of emotional closeness to their son (i.e. the father of the grandchild), ceteris paribus have a lower probability to disagree to this statement.

\footnotetext{
${ }^{21}$ The first two specifications (columns I and II) yield to statistically significant coeffcient estimates of the policy variable. The inclusion of the variable "age of child" (column III), however, decreases statistical precision. This is probably due to the fact that this variable is - by definition - strongly correlated with the policy variable "post07".
} 
Table 3: Estimation Results, linear probability model

\begin{tabular}{|c|c|c|c|c|c|c|c|c|}
\hline & \multicolumn{4}{|c|}{ Grandmothers } & \multicolumn{4}{|c|}{ Grandfathers } \\
\hline & I & II & III & IV & I & II & III & IV \\
\hline Post07 & $\begin{array}{l}0.1358^{+} \\
(0.076)\end{array}$ & $\begin{array}{l}0.1922^{*} \\
(0.086)\end{array}$ & $\begin{array}{l}0.2799^{\star} \\
(0.142)\end{array}$ & $\begin{array}{l}0.2804^{*} \\
(0.141)\end{array}$ & $\begin{array}{l}0.1912^{*} \\
(0.084)\end{array}$ & $\begin{array}{l}0.2103^{*} \\
(0.095)\end{array}$ & $\begin{array}{l}0.2212 \\
(0.180)\end{array}$ & $\begin{array}{l}0.2175 \\
(0.181)\end{array}$ \\
\hline Age & & $\begin{array}{l}-0.0173^{*} \\
(0.008)\end{array}$ & $\begin{array}{l}-0.0173^{*} \\
(0.008)\end{array}$ & $\begin{array}{l}-0.0176^{*} \\
(0.008)\end{array}$ & & $\begin{array}{l}-0.0114 \\
(0.009)\end{array}$ & $\begin{array}{l}-0.0115 \\
(0.009)\end{array}$ & $\begin{array}{l}-0.0122 \\
(0.009)\end{array}$ \\
\hline Years of education & & $\begin{array}{l}0.0234 \\
(0.018)\end{array}$ & $\begin{array}{l}0.0221 \\
(0.018)\end{array}$ & $\begin{array}{l}0.022 \\
(0.018)\end{array}$ & & $\begin{array}{l}0.0311 \\
(0.019)\end{array}$ & $\begin{array}{l}0.0309 \\
(0.020)\end{array}$ & $\begin{array}{l}0.0301 \\
(0.020)\end{array}$ \\
\hline Working when kids u6 & & $\begin{array}{l}0.0792 \\
(0.098)\end{array}$ & $\begin{array}{l}0.0973 \\
(0.101)\end{array}$ & $\begin{array}{l}0.0967 \\
(0.102)\end{array}$ & & & & \\
\hline Currently Employed & & $\begin{array}{l}-0.010 \\
(0.106)\end{array}$ & $\begin{array}{l}-0.009 \\
(0.107)\end{array}$ & $\begin{array}{l}-0.009 \\
(0.108)\end{array}$ & & $\begin{array}{l}-0.071 \\
(0.131)\end{array}$ & $\begin{array}{l}-0.071 \\
(0.132)\end{array}$ & $\begin{array}{l}-0.056 \\
(0.132)\end{array}$ \\
\hline Frequent contact & & $\begin{array}{l}0.0647 \\
(0.092)\end{array}$ & $\begin{array}{l}0.0759 \\
(0.092)\end{array}$ & $\begin{array}{l}0.0749 \\
(0.092)\end{array}$ & & $\begin{array}{l}0.0779 \\
(0.102)\end{array}$ & $\begin{array}{l}0.0782 \\
(0.103)\end{array}$ & $\begin{array}{l}0.0837 \\
(0.103)\end{array}$ \\
\hline Emotional closeness & & $\begin{array}{l}-0.132^{+} \\
(0.078)\end{array}$ & $\begin{array}{l}-0.131^{+} \\
(0.078)\end{array}$ & $\begin{array}{l}-0.132^{+} \\
(0.079)\end{array}$ & & $\begin{array}{l}0.0419 \\
(0.111)\end{array}$ & $\begin{array}{l}0.0430 \\
(0.112)\end{array}$ & $\begin{array}{l}0.0223 \\
(0.116)\end{array}$ \\
\hline Migration background & & $\begin{array}{l}0.0524 \\
(0.117)\end{array}$ & $\begin{array}{l}0.0486 \\
(0.118)\end{array}$ & $\begin{array}{l}0.0476 \\
(0.118)\end{array}$ & & $\begin{array}{l}-0.111 \\
(0.129)\end{array}$ & $\begin{array}{l}-0.113 \\
(0.129)\end{array}$ & $\begin{array}{l}-0.120 \\
(0.132)\end{array}$ \\
\hline Age (father) & & $\begin{array}{l}0.0323^{\star *} \\
(0.011)\end{array}$ & $\begin{array}{l}0.031^{* *} \\
(0.011)\end{array}$ & $\begin{array}{l}0.031^{\star \star} \\
(0.011)\end{array}$ & & $\begin{array}{l}0.017 \\
(0.012)\end{array}$ & $\begin{array}{l}0.017 \\
(0.012)\end{array}$ & $\begin{array}{l}0.017 \\
(0.012)\end{array}$ \\
\hline Years of edu (father) & & $\begin{array}{l}-0.0153 \\
(0.017)\end{array}$ & $\begin{array}{l}-0.0133 \\
(0.017)\end{array}$ & $\begin{array}{l}-0.0138 \\
(0.017)\end{array}$ & & $\begin{array}{l}-0.0027 \\
(0.018)\end{array}$ & $\begin{array}{l}-0.0026 \\
(0.019)\end{array}$ & $\begin{array}{l}-0.0041 \\
(0.019)\end{array}$ \\
\hline Child age & & & $\begin{array}{l}-0.029 \\
(0.039)\end{array}$ & $\begin{array}{l}-0.029 \\
(0.039)\end{array}$ & & & $\begin{array}{l}-0.004 \\
(0.050)\end{array}$ & $\begin{array}{l}-0.003 \\
(0.051)\end{array}$ \\
\hline Delta child care quota & & & & $\begin{array}{l}0.1389 \\
(0.597)\end{array}$ & & & & $\begin{array}{l}0.6749 \\
(0.721)\end{array}$ \\
\hline Constant & $\begin{array}{l}0.2093^{\star *} \\
(0.061)\end{array}$ & $\begin{array}{l}-0.0596 \\
(0.496)\end{array}$ & $\begin{array}{l}0.0416 \\
(0.517)\end{array}$ & $\begin{array}{l}0.0341 \\
(0.522)\end{array}$ & $\begin{array}{l}0.1379^{*} \\
(0.065)\end{array}$ & $\begin{array}{l}-0.048 \\
(0.663)\end{array}$ & $\begin{array}{l}-0.029 \\
(0.713)\end{array}$ & $\begin{array}{l}-0.089 \\
(0.730) \\
\end{array}$ \\
\hline Observations & 156 & 156 & 156 & 156 & 108 & 108 & 108 & 108 \\
\hline $\mathrm{R}^{2}$ & 0.017 & 0.138 & 0.142 & 0.142 & 0.036 & 0.142 & 0.142 & 0.150 \\
\hline Adj. $R^{2}$ & 0.011 & 0.032 & 0.029 & 0.022 & 0.027 & -0.009 & -0.020 & -0.022 \\
\hline Wave 3 dummy & No & Yes & Yes & Yes & No & Yes & Yes & Yes \\
\hline Regional dummies & No & Yes & Yes & Yes & No & Yes & Yes & Yes \\
\hline $\begin{array}{l}\text { Pre-mean } \\
\text { Post-mean }\end{array}$ & $\begin{array}{l}0.209 \\
0.345\end{array}$ & & & & $\begin{array}{l}0.138 \\
0.329\end{array}$ & & & \\
\hline
\end{tabular}

Note: Heteroscedasticity-consistent standard errors in parentheses.

${ }^{+} p<0.1,{ }^{*} p<0.05,{ }^{* *} p<0.01$

Source: pairfam, waves 3 (2010/11) and 5 (2012/13).

The dichotomous operationalization of the attitudes towards gender roles as presented in

the regression results in Table 3 has the disadvantage that it does not exploit the

information on the whole distribution of the variable that is defined on a 5 point Likert

scale. As an alternative specification, we therefore run ordered probit regressions for our

preferred specification (inclusion of socio-demographic characteristics, regional dummies, a

dummy for wave 3 , as well as child age and the regional increase in childcare availability). 
Table 4: Estimation Results, ordered probit model

\begin{tabular}{|c|c|c|}
\hline \multirow{2}{*}{ Post07 } & Grandmothers & Grandfathers \\
\hline & $\begin{array}{l}-0.7204^{*} \\
(0.331)\end{array}$ & $\begin{array}{l}-0.3442 \\
(0.455)\end{array}$ \\
\hline Age & $\begin{array}{l}0.0549 * \star \\
(0.021)\end{array}$ & $\begin{array}{l}0.0292 \\
(0.025)\end{array}$ \\
\hline Years of education & $\begin{array}{l}-0.0524 \\
(0.036)\end{array}$ & $\begin{array}{l}-0.0958^{\star} \\
(0.045)\end{array}$ \\
\hline Working when kids u6 & $\begin{array}{l}-0.3719^{+} \\
(0.220)\end{array}$ & \\
\hline Currently Employed & $\begin{array}{l}0.0335 \\
(0.260)\end{array}$ & $\begin{array}{l}0.0986 \\
(0.333)\end{array}$ \\
\hline Frequent contact & $\begin{array}{l}-0.0236 \\
(0.193)\end{array}$ & $\begin{array}{l}-0.3827 \\
(0.260)\end{array}$ \\
\hline Emotional closeness & $\begin{array}{l}0.3866^{*} \\
(0.192)\end{array}$ & $\begin{array}{l}0.4149 \\
(0.277)\end{array}$ \\
\hline Migration background & $\begin{array}{l}0.039 \\
(0.294)\end{array}$ & $\begin{array}{l}0.5684 \\
(0.487)\end{array}$ \\
\hline Age (father) & $\begin{array}{l}-0.0598^{\star} \\
(0.028)\end{array}$ & $\begin{array}{l}-0.0242 \\
(0.031)\end{array}$ \\
\hline Years of edu (father) & $\begin{array}{l}0.0275 \\
(0.036)\end{array}$ & $\begin{array}{l}0.0457 \\
(0.044)\end{array}$ \\
\hline Child age & $\begin{array}{l}0.1234 \\
(0.091)\end{array}$ & $\begin{array}{l}-0.0200 \\
(0.117)\end{array}$ \\
\hline Delta child care quota & $\begin{array}{l}-0.7607 \\
(1.526)\end{array}$ & $\begin{array}{l}-2.080 \\
(1.681)\end{array}$ \\
\hline Wave 3 & $\begin{array}{l}0.1736 \\
(0.287)\end{array}$ & $\begin{array}{l}-0.0799 \\
(0.333)\end{array}$ \\
\hline Regional dummies & yes & yes \\
\hline $\begin{array}{l}\mu_{1} \\
\mu_{2} \\
\mu_{3} \\
\mu_{4}\end{array}$ & $\begin{array}{l}-0.2044 \\
0.3605 \\
1.2768 \\
1.8721\end{array}$ & $\begin{array}{l}-1.5976 \\
-1.1466 \\
0.1315 \\
0.6334\end{array}$ \\
\hline$\frac{\partial \operatorname{Pr}(1)}{\partial P O S T 07}$ & $\begin{array}{l}0.134^{*} \\
(0.053)\end{array}$ & $\begin{array}{l}0.07 \\
(0.085)\end{array}$ \\
\hline$\frac{\partial \operatorname{Pr}(2)}{\partial P O S T 07}$ & $\begin{array}{l}0.073^{\star} \\
(0.032)\end{array}$ & $\begin{array}{l}0.03 \\
(0.043)\end{array}$ \\
\hline$\frac{\partial \operatorname{Pr}(3)}{\partial P O S T 07}$ & $\begin{array}{l}0.042 \\
(0.032)\end{array}$ & $\begin{array}{l}0.009 \\
(0.027)\end{array}$ \\
\hline$\frac{\partial \operatorname{Pr}(4)}{\partial P O S T 07}$ & $\begin{array}{l}-0.05^{\star *} \\
(0.018)\end{array}$ & $\begin{array}{l}-0.031 \\
(0.04)\end{array}$ \\
\hline$\frac{\partial \operatorname{Pr}(5)}{\partial P O S T 07}$ & $\begin{array}{l}-0.193^{* *} \\
(0.096)\end{array}$ & $\begin{array}{l}0.079 \\
(0.111)\end{array}$ \\
\hline $\begin{array}{l}\text { Observations } \\
\text { Log-Likelihood } \\
\text { Chi Squared }\end{array}$ & $\begin{array}{l}156 \\
-231.487 \\
28.162\end{array}$ & $\begin{array}{l}108 \\
-148.314 \\
23.442\end{array}$ \\
\hline
\end{tabular}

Note: Standard errors in parentheses.

${ }^{+} p<0.1,{ }^{*} p<0.05,{ }^{* *} p<0.01$

Source: pairfam, waves 3 (2010/11) and 5 (2012/13).

As Table 4 shows, the ordered probit estimation confirms the results from the linear

probability model. Grandmothers who have sons with a child born after 2007 are 13.4

percentage points more likely to "fully disagree" and 7.3 percentage points more likely to

"disagree" with the statement "Women should be more concerned about their family than 
about their career" than grandmothers whose sons got a child before this date. As in the linear probability model, the effects for grandfathers are estimated with much lower precision.

\section{Conclusion}

Policy programs such as fathers' quota in parental leave are often argued not only to serve as means to change behavior of the target group but also potentially change attitudes towards gender roles and stereotypes within society as a whole. Germany introduced such a program within the parental leave reform of 2007. As a result, the share of fathers who took (at least two months of) parental leave increased sharply from less than three percent in 2006 to 34 percent ten years later.

In this paper, we analyze whether the introduction of the fathers' quota in parental leave has changed the attitudes towards gender roles in the grandparents' generation. To this end, we exploit the quasi-experimental setting of the 2007 reform and compare grandparents whose son had a child born shortly before the 2007 reform to grandparents whose son had a child born shortly after it.

Our findings show a positive impact of the fathers' quota in parental leave on attitudes concerning gender equality. Specifically, we find that grandmothers whose sons had children who were born after the reform are less likely to agree to the statement "Women should be more concerned about their family than about their career". For grandfathers, we find point estimates of similar direction and magnitude, which are, however, estimated with lower statistical precision due to the small size of the sample. 
The results suggest that the formation of gender role attitudes is not finished at a certain age. Moreover, attitudes towards gender roles are not only transmitted from parents to children but also from (grown-up) children to their parents.

From a policy perspective, these results provide evidence that programs such as father's quota within parental leave schemes not only induce direct behavioral responses by the target group but also have indirect effects on non-treated individuals through social interaction. Changes in the attitudes of the grandparent generation might produce even more spillover effects if their attitudes affect younger children within the family, or - if the grandparents are still engaged in the labor market - their younger coworkers. These spillover effects might finally explain why we find a steady increase of the share of fathers taking parental leave even one decade after the 'daddy months' were initially introduced. Overall, our results suggest that policy programs like fathers' quota in parental leave indeed are suitable to change attitudes towards gender roles in society as a whole. 


\section{References}

Akerlof, G.A. and R.E. Kranton (2000): Economics and Identity, The Quarterly Journal of Economics 65(3), 715-753.

Angelucci, M, De Giorgi, G., Rangel, M. and I. Rasul (2010): Family networks and school enrolment: Evidence from a randomized social experiment. Journal of Public Economics 94 (3-4), 197-221.

Bauernschauster, S. and H. Rainer (2012): Political regimes and the family: how sex-role attitudes continue to differ in reunified Germany, Journal of Population Economics 25(1), 5-27.

Bergemann, A. and R. Riphahn (2011): Female Labor Supply and parental leave benefits - the causal effects of paying higher transfers for a shorter period of time, Applied Economics Letters 18 (1), 17-20.

Bertrand, M., E. Luttmer and S. Mullainathan (2000): Network Effects and Welfare Cultures, Quarterly Journal of Economics 155 (3), 1019-1055.

Blohm, M. and J. Walter (2016): Traditionelle und egalitäre Einstellungen zur Rolle der Frau im Zeitverlauf, in: Datenreport 2016 der Bundeszentrale für politische Bildung, retrieved on 3/30/2017 from http://www.bpb.de/nachschlagen/datenreport-2016/226975/rolle-der-frau.

Brown, K. M. and R. A. Laschever (2012): When They're Sixty-Four: Peer Effects and the Timing of Retirement, American Economic Journal: Applied Economics 4 (3), 90-115.

Cools, S., J.H. Fiva and L.J. Kirkebøen (2015): Causal Effects of Paternity Leave on Children and Parents, Scandinavian Journal of Economics 117(3), 801-828.

Cunningham, M. (2001): The Influence of Parental Attitudes and Behaviors on Children's Attitudes Toward Gender And Household Labor in Early Adulthood, Journal of Marriage and the Family 63, 111-122.

Dahl, G., Mogstad, M. and K. Løken (2014): Peer Effects in Program Participation, American Economic Review, 104(7), 2049-2074.

Ellingsaeter, A.L., R.H. Kitterod and J. Lyngstad (2016): Universalising Childcare, Changing Mothers' Attitudes: Policy Feedback in Norway, Journal of Social Policy 46 (1), 149-173.

Farré, L. and F. Vella (2013): The intergenerational transmission of gender role attitudes and its implications for female labor force participation, Economica 80, 219-247.

Fernandez, R., A. Fogli and C. Olivetti (2004): Mothers and Sons: Preference Formation and Female Labor Force Dynamics, Quarterly Journal of Economics 119(4), 1249-1299.

Fortin, N.M. (2005): Gender Role Attitudes and the Labour-Market outcomes of women acress OECD countries, Oxford Review of Economic Policy 21 (3), 416-438. 
Fortin, N.M. (2015): Gender Role Attitudes and Women's Labor Market Participation: OptingOut, AIDS, and the Persistent Appeal of Housewifery, Annals of Economics and Statistics $117 / 118,379-401$.

Geisler, E. and M. Kreyenfeld (2012): How policy matters: Germany's parental leave reform and fathers' behavior 1999-2009. Max Planck Institute for Demographic Research Working Paper 2012-021.

Geyer, J., P. Haan and K. Wrohlich (2015): The effects of family policy on maternal labour supply: Combining evidence from a structural model and a quasi-experimental approach, Labour Economics 36, 84-98.

Hanel, B. and R. Riphahn (2012): The Employment of Mothers - Recent Developments and their Determinants in East and West Germany, Jahrbücher für Nationalökonomie und Statistik 232 (2) 146-176.

Huerta, M.C., Adema, W., Baxter, J., Han, W.-J., Lausten, M., Lee, RH, Waldfogel, J (2013): Fathers' leave, fathers' invovlement and child development: Are they related? Evidence from four OECD countries. OECD Social, Employment and Migration Working Papers No. 140.

Huinink, J., J. Brüderl, B. Nauck, S. Walper, L. Castiglioni and M. Feldhaus (2011): Panel Analysis of Intimate Relationships and Family Dynamics (pairfam): Conceptual framework and design, Zeitschrift für Familienforschung (Journal of Family Research), 23(1), 77-101.

Kling, J.R., J. Ludwig and L. F. Katz (2005): Neighbourhood effects on crime for female and male youth: Evidence from a randomized housing voucher experiment, Quarterly Journal of Economics 120 (1), 87-130.

Kluve, J. and M. Tamm (2013): Parental leave regulations, mothers' labor force attachment and fathers' childcare involvement: evidence from a natural experiment, Journal of Population Economics 26 (3), 983-1005.

Kotsadam, A. and H. Finseraas (2011): The state intervenes in the battle of sexes: Causal effects of paternity leave, Social Science Research 40(6), 1611-1622.

Lalive, R. and M. A. Cattaneo (2009): Social Interactions and Schooling Decisions, Review of Economics and Statistics 91 (3), 457-477.

Manski, C. F. (1993): Identification of Endogenous Social Effects: The Reflection Problem, The Review of Economic Studies 60 (3), 531-542.

Meier, V. and H. Rainer (2017), Daddy Months, Journal of Population Economics, forthcoming.

Moffitt, R. (2001): Policy Interventions, Low-Level Equilibria and Social Interactions, In: Social dynamics. Ed. By S. N. Durlauf and P. H. Young. Cambridge MIT Press, Chapter 3, 45-82.

Müller, K. and K. Wrohlich (2016): Two Steps Forward - One Step Back? Evaluating Contradicting Child Care Policies in Germany. Cesifo Economic Studies, 62 (2016), 4, S. S. 672-698. 
Olivetti, C., E. Patacchini and Y. Zenou (2016): Mothers, Peers and Gender Identity. Mimeo.

Sacerdote, B. (2001): Peer Effects with Random Assignment: Results for Dartmouth Roommates, Quarterly Journal of Economics 116, 681-704.

Schober, P.S. (2014): Parental Leave and Domestic Work of Mothers and Fathers: A Longitudinal Study of Two Reforms in West Germany, Journal of Social Policy 43(2), 351-372.

Sjöberg, O. (2004): The Role of Family Policy Institutions in Explaining Gender Role Attitudes: A Comparative Multilevel Analysis of Thirteen Industrialized Countries, Journal of European Social Policy 14 (2), 107-123.

Steiner, V. and K. Wrohlich (2004): Household Taxation, Income Splitting and Labour Supply Incentives - A Microsimulation Study for Germany, CESifo Economic Studies 50(3), 541-568.

Suckow, J., U. Schneekloth and P. Wich (2010): Beziehungen und Familienleben in Deutschland (2009/2010) Welle 2. Tech. Rep. München: TNS Infratest Sozialforschung.

Terjesen, S., Aguilera, R.V. \& Lorenz, R. (2015): Legislating a Women's Seat on the Board: Institutional Factors Driving Gender Quotas for Boards of Directors, Journal of Business Ethics $128,233-251$.

Welteke C. and K. Wrohlich (2016): Peer Effects in Parental Leave, IZA Discussion Paper No. 10173.

Wrohlich, K. (2008): The Excess Demand for Subsidized Child Care in Germany, Applied Economics, 40(10) 1217-1228.

Wrohlich, K., Berger, E., Geyer, J., Haan, P., Sengül, D., Spiess C.K. and A. Thiemann (2012): Elterngeld Monitor. DIW Berlin: Politikberatung kompakt No. 61. 